\title{
Brazil's New Biodiversity Law
}

James R. Welch

Author address: Escola Nacional de Saúde Pública, Fundação Oswaldo Cruz, Rua Leopoldo Bulhões 1480, Rio de Janeiro, RJ, 20911-300, Brazil.

Email: welch@ensp.fiocruz.br

Received: December 20, 2015

Volume: 6(1):216-217

Published: December 21, 2015

(C) 2015 Society of Ethnobiology

In 1992, 168 countries signed the Convention on Biological Diversity, a multilateral treaty addressing conservation, sustainable use, and benefit sharing of genetic and biodiversity resources. With the exception of the United States, all United Nations member states, including Brazil, have ratified the treaty. In April 2015 Brazil's legislature passed Law 13123, known as the new "Biodiversity Law" (Brazil 2015), which came into effect on November 17, 2015 and regulates the country's internal mechanisms for complying with the treaty, including measures addressing access to genetic resources and related traditional knowledge, as well as equitable sharing of benefits resulting from their commercial use. The move was applauded by representatives of some important public institutions in Brazil as a victory for researchers (da Silva 2015) and for Indigenous and traditional peoples (Tolentino and Assis 2015).

Despite receiving praise from some quarters, the new law may have been enacted through a process marred by major legal oversights, including inadequate previous consultation with Indigenous peoples, as required by the International Labour Organization Convention No. 169 on Indigenous and Tribal Peoples (Távora et al. 2015). In fact, Indigenous and traditional peoples, with the support of many academic societies and international organizations, issued a letter of repudiation arguing that they were not consulted and their interests were insufficiently addressed (Ascom/Consea 2015). Furthermore, since its ratification, statutory implementation stalled late this year, perhaps in part because the country's Indigenous and traditional peoples boycotted the public consultation process. According to Cristiane Julião of the Articulation of Indigenous Peoples and Organizations of the Northeast, "They brought us just to say yes. And we said no" (Diniz 2015).

In some respects, the new Biodiversity Law seeks to improve upon Brazil's previous biodiversity law,
Provisional Measure 2186-16 (Brazil 2001), which also sought to implement parts of the Convention on Biological Diversity but was overwhelmingly criticized for discouraging biological and ethnobiological research, innovation, and international collaboration (da Silva 2015; Escobar 2015). In particular, the new law facilitates research and commercialization of products by eliminating federal authorization for most kinds of research and clearly specifying the quantities, beneficiaries, and mechanisms of benefit sharing. In fact, it gives a free pass for past irregularities and noncompliance with Provisional Measure 2186-16, forgiving applicable fines for activities regularized within one year.

Differently than the Provisional Measure 2186-16, which required prior federal authorization to conduct ethnobiological research, the new law stipulates registration through an online system at any time before depositing collections, publishing results, or commercializing products. Simply completing this registration is expected to generate an electronic declaration of legal compliance irrespective of whether an endeavor actually follows the spirit of the law or was duly approved by study communities. In other words, compliance will be reduced to an administrative act by the interested researcher, company, or other party. However, until this registry system is designed and implemented along with other provisions of the law, it is unknown at this stage whether additional protections will be incorporated.

Benefit sharing, which will be tracked in a publicly accessible online system, is to be fixed at 0.1 to $1 \%$ of annual net receipts and deposited in a special governmental fund. Exemptions and exceptions are contemplated for pre-consumer products, intermediaries, small producers, traditional farmers, and upon special request by interested parties for the sake of economic competitiveness. Non-monetary benefit sharing is also allowed. 
Many will be surprised by the new law's reach, which encompasses all research and use related to genetic information (plant, animal, and microbial species, among others) encountered anywhere within the national territory, continental shelf, territorial sea, or exclusive economic zone. This includes, for example, such diverse types of studies as taxonomy, description of new species, biological inventories, ecology, biogeography, and epidemiology (da Silva 2015). Access to associated traditional knowledge covered by the law includes not only original research with identifiable peoples and communities, but also studies of information originated from "unidentifiable" populations or obtained from secondary sources, such as publications, inventories, films, and other records. Noncompliance with the new law is punishable by fines up to $\mathrm{R} \$ 100,000$ and $\mathrm{R} \$ 100,000,000$ for individuals and businesses, respectively, as well as seizure of collections and products.

In addition to provoking strong negative reactions by a long list of Indigenous organizations, passage of the new Biodiversity Law has led to a temporary regulatory quagmire. Because Law 13123 has yet to be implemented by means of specific decree but nevertheless already revoked Provisional Measure 2186-16, as of the publication of this editorial there are no specific guidelines or protocols in effect for many aspects of ethnobiological research in the country. Consequently, researchers must temporarily operate without knowledge of the requirements to which they will be subjected regarding prior informed consent, project registration, public deposit of findings, and handling of genetic material.

Criticism aside, there appears to be ample political will to implement Brazil's new Biodiversity Law. Doing so will take time and may lead to further chaos as research, development, and commercialization continue in the absence of specific statutory guidelines. But the real test of the law's success will be after implementation, when it becomes apparent if its vast scope and lack of protections of Indigenous and traditional peoples' rights lead to abuses. In the meantime, however, researchers can rest assured that the former quasi-criminalization of routine academic research and fair commercial use in Brazil is now a thing of the past.

\section{References Cited}

Ascom/Consea. 2015. Moção Critica Projeto sobre a Biodiversidade. Available at: http:// www4.planalto.gov.br/consea/comunicacao/ noticias $/ 2015 / \mathrm{marco} / \mathrm{mocao}-$ critica-projeto-sobre-a -biodiversidade. Accessed on December 17, 2015.

Brazil. 2001. Medida Provisória no 2.186-16, de 23 de Agosto de 2001. Available at: http:// www.planalto.gov.br. Accessed on December 17, 2015.

Brazil. 2015. Lei no 13.123, de 20 de Maio de 2015. Available at: http://www.planalto.gov.br. Accessed on December 17, 2015.

Diniz, M. 2015. 'Nos Trouxeram só para Dizer Sim', Diz Indígena sobre a Lei da Biodiversidade. Available at: http:/ /agenciabrasil.ebc.com.br/ direitos-humanos/noticia/2015-10/nos-trouxeramso-para-dizer-sim-diz-indigena-sobre-lei-da. Accessed on December 17, 2015.

Escobar, H. 2015. Brazil Cuts Red Tape Stifling Biodiversity Studies. Science Magazine 348:952-953. Doi: 10.1126/science.348.6238.952.

Silva, M. 2015. A Nova Lei da Biodiversidade e Seu Impacto na Área de Pesquisa. Available at: http:// agencia.fiocruz.br/nova-lei-da-biodiversidade-e-seuimpacto-na-área-de-pesquisa. Accessed on December 17, 2015.

Távora, F. L., H. J. F. Neto, L. M. C. Póvoa, K. Kässmayer, L. B. G. Souza, V. M. Pinheiro, F. Basile, and D. M. N. Carvalho. Comentários à Lei n ${ }^{\circ}$ 13.123, de 20 de Maio de 2015: Novo Marco Regulatório do Uso da Biodiversidade (Texto para Discussão no 184). Núcleo de Estudos e Pesquisas/ CONLEG/Senado, Brasilia. Available at: http:// www.senado.leg.br/estudos. Accessed on: December 17, 2015.

Tolentino, L., and L. Assis. 2015. Sancionado o Marco Legal da Biodiversidade. Available at: http://

www.mma.gov.br. Accessed on December 17, 2015.

\section{Biosketch}

James R. Welch is Associate Professor of human ecology and health at the National School of Public Health, Rio de Janeiro, and co-editor of Ethnobiology Letters. His anthropological research focuses on the interface between environment, culture, and health among indigenous peoples in Brazil. 